\author{
PaWel Gata ${ }^{1}$
}

\title{
Kilka uwag w przedmiocie projektu nowelizacji ustawy o ochronie prawnej odmian roślin
}

\section{Zagadnienia wstępne}

System ochrony prawnej odmian roślin w Polsce opiera się na trzech filarach. Pierwszy z nich stanowi Międzynarodowa konwencja ochrony nowych odmian roślin² przyjęta w Paryżu w dniu 2 grudnia 1961 r. Polska jest związana tą Konwencją od 11 listopada 1989 r., a od 15 sierpnia 2003 r. jest stroną jej najnowszej wersji z 1991 r. Członkiem Konwencji UPOV od 29 lipca 2005 r. jest także Unia Europejska. Zgodnie z przepisami art. 30 Konwencji UPOV, nakłada ona na swoich sygnatariuszy obowiązek wdrożenia jej postanowień do wewnętrznych porządków prawnych umawiających się stron. Tym samym zarówno Polska, jak i Unia Europejska, jako sygnatariusze Konwencji, zobligowani byli do przyjęcia stosownych przepisów prawa regulujących problematykę ochrony prawnej odmian roślin.

Konwencja UPOV jest zatem źródłem dwóch pozostałych grup przepisów statuujących ochronę wyłącznego prawa do odmian roślin w Polsce. Na szczeblu krajowym są to przepisy ustawy z dnia 26 czerwca 2003 r. o ochronie prawnej odmian roślin ${ }^{3}$, zaś na szczeblu wspólnotowym - przepisy rozporządzenia Rady (WE) nr 2100/94 z dnia 27 lipca 1994 r. w sprawie wspólnotowego systemu ochrony odmian roślin ${ }^{4}$ wraz z przepisami wykonawczymi ${ }^{5}$. Obydwie ww. grupy regulacji prawnych funkcjonują w Polsce równolegle. Wyłącznie od decyzji uprawnionego podmiotu (hodowcy) zależy, w oparciu o które spośród nich chronił będzie swoje odmiany roślin. Jeżeli w stosunku do konkretnej odmiany złoży wniosek o przy-

$1 \quad$ Uniwersytet Śląski w Katowicach.

2 Międzynarodowa konwencja ochrony nowych odmian roślin zawarta w Paryżu 2 grudnia 1961 r. była następnie rewidowana w Genewie 10 listopada 1972 r., 23 października 1978 r. oraz 19 marca 1991 r. Powszechnie używa się na jej określenie nazwy Konwencja UPOV, która pochodzi od powstałego na podstawie Konwencji Związku Ochrony Nowych Odmian Roślin (franc. Union pour la Protection des Obtentions Végétales) - tekst konwencji dostępny jest na stronie: http://www.upov.int/upovlex/en/conventions/1978/act 1978.html.

3 Tekst jednolity Dz.U. z 2016 r. poz. 843.

Dz.Urz. WE L 227 z 1.09.1994 r., s. 1-30.

Spośród, których najistotniejsze znaczenie ma rozporządzenie Komisji (WE) nr 1768/95 z 24.07.1995 r. ustanawiające przepisy wykonawcze $\mathrm{w}$ zakresie odstępstwa rolnego przewidzianego $\mathrm{w}$ art. 14 ust. 3 rozporządzenia Rady (WE) nr 2100/94 w sprawie wspólnotowego systemu ochrony odmian roślin (Dz.Urz. WE L 173 z 25.07.1995 r.), s. 14-21. 
znanie ochrony krajowej, do wyłącznego prawa do tej odmiany zastosowanie znajdą przepisy ustawy o ochronie prawnej odmian roślin. Jeżeli wystąpi o przyznanie ochrony wspólnotowej i ochronę taką uzyska, będzie ona bazować na przepisach rozporządzenia Rady (WE) nr 2100/94. Zarówno przepisy Unii Europejskiej6, jak i korespondujące $\mathrm{z}$ nimi uregulowania krajowe ${ }^{7}$ wykluczają możliwość łączenia ochrony w ramach systemu krajowego oraz wspólnotowego. Uzyskanie ochrony na szczeblu wspólnotowym z mocy samego prawa uniemożliwia uzyskanie ochrony na szczeblu krajowym, a jeżeli ochrona krajowa została przyznana wcześniej, to zostaje ona zawieszona na czas trwania ochrony wspólnotowej.

Niezależnie od przyjętego modelu ochrony wyłącznego prawa do odmian roślin (krajowego czy też wspólnotowego), jego treść zawiera się w ustanowieniu na rzecz podmiotu uprawnionego (hodowcy) monopolu w zakresie korzystania z materiału siewnego odmiany objętej ochroną. Wyłącznie hodowca uprawniony jest bowiem do: wytwarzanie lub rozmnażania, przygotowania do rozmnażania, oferowania do sprzedaży, sprzedaży i innych form zbywania, eksportu, importu oraz przechowywania materiału siewnego odmiany (odpowiednio art. 21 ustawy o ochronie prawnej odmian roślin oraz art. 13 ust. 2 rozporządzenia Rady (WE) nr 2100/94). Monopol ten pozwala hodowcy na zarobkowe korzystanie $\mathrm{z}$ wyłącznego prawa do odmiany. Podstawowym bowiem sposobem czerpania przez hodowcę korzyści z tytułu wyłącznego prawa do odmian roślin jest udzielanie podmiotom zainteresowanym licencji, w ramach których hodowca - w zamian za opłatę licencyjną - upoważnia licencjobiorców do dokonywania określonych czynności w stosunku do materiału siewnego odmiany objętej ochroną. Najczęściej hodowca upoważnia licencjobiorcę do rozmnożenia materiału siewnego, przygotowania namnożonego materiału siewnego do siewu, oferowania takiego materiału do sprzedaży oraz do jego sprzedaży odbiorcom końcowym (rolnikom).

Możliwość zarobkowego korzystania z wyłącznego prawa do odmian roślin nie tylko motywuje hodowców do dalszej pracy twórczej, czyli do hodowania nowych odmian roślin, ale także dostarcza środków do prowadzenia takiej twórczej hodowli. Bez możliwości czerpania korzyści z tytułu prawa do odmian roślin nie byłoby możliwe finansowanie nowych prac hodowlanych.

\section{Ograniczenia wyłącznego prawa do odmian roślin}

Wyłączne prawo do odmian roślin nie ma jednak charakteru monopolu absolutnego. Podobnie jak i inne prawa własności intelektualnej doznaje ono różnego rodzaju ograniczeń. Wśród ograniczeń tych wymienić można: jego czasowy charakter 
(wyłączne prawo do odmian roślin przyznawane jest na określony $\mathrm{czas}^{8}$ ), przywilej hodowcy (nie stanowi naruszenia wyłącznego prawa do odmian roślin wykorzystywanie materiału siewnego do tworzenia nowych odmian ${ }^{9}$ ), prawo do korzystania z materiału siewnego dla własnych, niezarobkowych celów ${ }^{10}$, prawo do korzystania $\mathrm{z}$ materiału siewnego w celach doświadczalnych ${ }^{11}$, wyczerpanie wyłącznego prawa do odmiany (możliwość podejmowania szeregu działań w stosunku do konkretnej partii materiału siewnego legalnie wprowadzonego do obrotu ${ }^{12}$ ), licencje ustawowe wyłącznego prawa do odmiany (licencja przymusowa ${ }^{13}$ oraz odstępstwo rolne ${ }^{14}$ ).

Spośród wskazanych wyżej ograniczeń wyłącznego prawa do odmian roślin, Konwencja UPOV tylko odstępstwo rolne traktuje jako ograniczenie fakultatywne. Oznacza to, że wszystkie pozostałe ograniczenia wyłącznego prawa do odmian roślin muszą znaleźć swoje odzwierciedlenie w przepisach wewnętrznych sygnatariuszy Konwencji, natomiast strona Konwencji może, ale nie musi wprowadzić do swojego porządku prawnego instytucję odstępstwa rolnego. Zgodnie bowiem z przepisami art. 15 ust. 2 Konwencji UPOV, każda z umawiających się stron może, w rozsądnych granicach oraz z uwzględnieniem ochrony prawnych interesów hodowcy, ograniczyć prawo hodowcy odnośnie do jakiejkolwiek odmiany w celu umożliwienia rolnikom wykorzystania do celów siewu, w ich gospodarstwach, plonu, który uzyskali, sadząc w swoich gospodarstwach chronioną odmianę.

Istotą odstępstwa rolnego jest zatem odstępstwo od przyjętego systemu ochrony odmian roślin w celu zabezpieczenia interesów rolników. Realizacja interesów rolników polega zaś na możliwości wykorzystywania przez nich we własnym gospodarstwie materiału ze zbioru odmiany chronionej jako materiału siewnego bez zgody hodowcy. Tak rozumiane odstępstwo rolne funkcjonuje zarówno we wspólnotowym, jak i krajowym modelu ochrony prawnej odmian roślin.

W obowiązującym stanie prawnym, zarówno w przypadku wspólnotowej, jak i krajowej instytucji odstępstwa rolnego, prawodawcy zadbali, by ustanowione w ten sposób ograniczenie wyłącznego prawa do odmian roślin miało rozsądne granice i uwzględniało konieczność ochrony uzasadnionych interesów hodowców. Granice instytucji wyznacza:

Por. art. 27 ustawy o ochronie prawnej odmian roślin oraz art. 19 rozporządzenia Rady (WE) nr 2100/94.

9 Por. art. 22 ust. 3 pkt 3 ustawy o ochronie prawnej odmian roślin oraz art. 15 pkt c) rozporządzenia Rady (WE) nr 2100/94.

10 Por. art. 22 ust. 3 pkt 1 ustawy o ochronie prawnej odmian roślin oraz art. 15 pkt a) rozporządzenia Rady (WE) nr 2100/94.

11 Por. art. 22 ust. 3 pkt 2 ustawy o ochronie prawnej odmian roślin oraz art. 15 pkt b) rozporządzenia Rady (WE) nr 2100/94.

12 Por. art. 28 ust. 1 ustawy o ochronie prawnej odmian roślin oraz art. 16 rozporządzenia Rady (WE) nr 2100/94.

13 Por. art. 31-34 ustawy o ochronie prawnej odmian roślin oraz art. 29 rozporządzenia Rady (WE) nr 2100/94.

14 Por. art. 23-23d ustawy o ochronie prawnej odmian roślin oraz art. 14 rozporządzenia Rady (WE) nr 2100/94. 
- możliwość korzystania przez rolników z odstępstwa rolnego wyłącznie w przypadku najważniejszych rolniczo gatunków roślin, których zamknięty katalog określają odpowiednie przepisy ${ }^{15}$,

- możliwość korzystania z odstępstwa rolnego bez żadnych obciążeń wyłącznie przez tzw. drobnych rolników ${ }^{16}$.

Uwzględniając zaś konieczność ochrony uzasadnionych interesów, tak prawodawca wspólnotowy, jak i krajowy skorelowali z uprawnieniami pozostałych rolników ${ }^{17}$ trzy obowiązki:

- obowiązek zapłaty przez rolnika korzystającego z instytucji odstępstwa rolnego, na rzecz uprawnionego hodowcy stosownej opłaty ${ }^{18}$,

- obowiązek udzielenia przez rolnika na rzecz hodowcy informacji o zakresie stosowania przez niego instytucji odstępstwa rolnego ${ }^{19}$, oraz

- obowiązek poddania się kontroli zgodności udzielonych informacji ze stanem faktycznym ${ }^{20}$.

Por. art. 14 ust. 2 rozporządzenia Rady (WE) nr 2100/94 oraz art. 23 ust. 2 ustawy o ochronie prawnej odmian roślin.

16 Przepisy dotyczące wspólnotowego odstępstwa rolnego, wprowadzają skomplikowany mechanizm pozwalający w oparciu o normy produkcyjne na ustalenie kategorii drobnych rolników. Regulacje pozwalające na określenie tej kategorii zawiera art. 14 ust. 3 pkt 3 rozporządzenia Rady (WE) nr 2100/94 oraz art. 7 rozporządzenia Komisji (WE) nr 1768/95 z 24.07.1995 r. ustanawiającego przepisy wykonawcze w zakresie odstępstwa rolnego przewidzianego w art. 14 ust. 3 rozporządzenia Rady (WE) nr 2100/94 w sprawie wspólnotowego systemu ochrony odmian roślin (Dz.Urz WE. L 173, 25.07.1995 r., str. 14-21). Więcej co do zasad określania kategorii „drobnych rolników" na gruncie przepisów wspólnotowych P. Gała, M. Korzycka-Iwanow, Ochrona prawna odmian roślin, (w:) System Prawa Prywatnego, Tom 14A, Prawo własności przemysłowej, R. Skubisz (red.), Warszawa 2012, s. 1036-1037. Przepisy dotyczące krajowego odstępstwa rolnego, w art. 23 ust. 3 ustawy o ochronie prawnej odmian roślin, nie definiując pojęcia „drobnego rolnika” wskazują, że opłaty z tytułu odstępstwa rolnego nie ponoszą posiadacze gruntów rolnych o powierzchni: do 10 ha - w przypadku, gdy korzystają z chronionych wyłącznym prawem odmian ziemniaka; do 25 ha - w przypadku, gdy korzystają z chronionych wyłącznym prawem odmian innych gatunków objętych odstępstwem rolnym. Więcej w przedmiocie określania kategorii „drobnych rolników" na gruncie przepisów krajowych P. Gała, M. Korzycka-Iwanow, Ochrona prawna odmian roślin, op. cit., s. $1035-1036$.

17 Innych niż „drobni rolnicy”.

18 Niezależnie od przyjętego systemu ochrony wyłącznego prawa do odmian roślin (krajowego lub wspólnotowego), strony są uprawnione przede wszystkim do określenia wysokości tej opłaty w drodze umowy (art. 23 ust. 4 ustawy o ochronie prawnej odmian roślin oraz art. 5 ust. $1 \mathrm{w}$ zw. z art. 3 ust. 2 rozporządzenia Komisji (WE) nr 1768/95). Dopiero w braku takiej umowy zastosowanie znajdują przepisy pozwalające na jej skalkulowanie. W przypadku krajowego odstępstwa rolnego wysokość tej opłaty stanowi $50 \%$ wartości opłaty licencyjnej pobieranej przez hodowcę danej odmiany (art. 23 ust. 5 ustawy o ochronie prawnej odmian roślin). W przypadku wspólnotowego odstępstwa rolnego, opłata ta powinna być w rozsądnym stopniu niższa od wysokości opłaty licencyjnej i winna być ustalana stosownie do jednolitego poziomu takiej opłaty na danym obszarze. Gdy zaś na danym obszarze brak jest możliwości ustalenia takiego jednolitego poziomu opłaty, winna ona stanowić $50 \%$ wartości opłaty licencyjnej (art. 5 ust. 2-5 rozporządzenia Komisji (WE) nr 1768/95).

19 Por. w przypadku odmian roślin chronionych na szczeblu wspólnotowym art. 14 ust. 3 pkt 6 rozporządzenia Rady (WE) nr 2100/94 oraz art. 8 rozporządzenia Komisji (WE) nr 1768/95, a w przypadku krajowego odstępstwa rolnego art. 23a ustawy o ochronie prawnej odmian roślin.

20 Por. w przypadku odmian roślin chronionych na szczeblu wspólnotowym art. 14 i 16 rozporządzenia Komisji (WE) nr 1768/95, a w przypadku krajowego odstępstwa rolnego art. 23c ustawy o ochronie prawnej odmian roślin. 
Przyjmując do wspólnotowego oraz krajowego systemu ochrony prawnej odmian roślin instytucję odstępstwa rolnego, prawodawca (tak wspólnotowy, jak i krajowy) miał na uwadze przede wszystkim interes rolników. Instytucja ta bowiem uniezależnia ich od monopolu hodowców nowych odmian roślin. Dzięki odstępstwu rolnemu rolnicy mogą korzystać do siewu z nasion (materiału siewnego) pozyskanych we własnym gospodarstwie bez konieczności uzyskiwania zgody hodowcy. Instytucja ta jednocześnie stanowi gwarancję bezpieczeństwa żywnościowego kraju. Gwarancja ta przejawia się w możliwości produkowania przez rolników żywności w oderwaniu od jakichkolwiek zewnętrznych ograniczeń prawnych.

Ustanawiając obowiązek zapłaty przez największych rolników korzystających z instytucji odstępstwa rolnego opłaty z tego tytułu ustawodawca, tak wspólnotowy, jak i krajowy, zagwarantował z kolei hodowcy możliwość rekompensaty co najmniej części strat spowodowanych utratą opłat licencyjnych z tytułu wykorzystania wyłącznego prawa do odmian roślin w ramach samozaopatrzenia gospodarstw w nasiona (materiał siewny). Ustawodawca zdawał sobie jednocześnie sprawę, że samo uprawnienie do opłat z tytułu korzystania $\mathrm{z}$ instytucji odstępstwa rolnego miałoby charakter iluzoryczny bez stworzenia mechanizmu prawnego pozwalającego hodowcy na ustalenie, czy konkretny rolnik korzystał z odstępstwa rolnego oraz jaki był zakres tego korzystania. Stąd też obok uprawnienia do opłaty, hodowcy przysługuje względem rolnika roszczenie informacyjne. Roszczenie to ma w istocie charakter kontrolny. Niezależnie bowiem od przyjętego modelu ochrony wyłącznego prawa do odmian roślin, rolnik zobowiązany jest do uiszczenia opłaty z tytułu odstępstwa rolnego bez wezwania ze strony hodowcy ${ }^{21}$. Uprawnienie informacyjne służyć ma zatem jedynie weryfikacji, czy rolnik korzystający z odstępstwa rolnego uiścił opłatę należną z tego tytułu.

Tak jak roszczenie informacyjne ma pomocniczy, weryfikacyjny charakter w stosunku do uprawnienia do uzyskania opłaty z tytułu odstępstwa rolnego, tak wskazane wyżej uprawnienie kontrolne służy możliwości sprawdzenia przez hodowcę, czy informacja udzielona przez rolnika jest zgodna ze stanem rzeczywistym. W ramach uprawnienia kontrolnego hodowca ma prawo domagania się: wglądu do dokumentów rolnika dotyczących korzystania z materiału siewnego, okazania gruntów rolnych, pomieszczeń i urządzeń magazynowych ${ }^{22}$.

Podkreślić należy, że jedynie połączenie w ramach odstępstwa rolnego uprawnień hodowcy do opłaty z roszczeniami: informacyjnym i kontrolnym, gwarantuje ochronę słusznych interesów hodowcy. Bez prawa do opłaty za korzystanie z materiału siewnego pochodzącego z własnego zbioru, hodowca nie mógłby liczyć na uzy-

21 P. Gała, M. Korzycka-Iwanow, Ochrona prawna odmian roślin, op. cit., s. 1040.

22 Por. w przypadku odmian roślin chronionych na szczeblu wspólnotowym art. 14 ust. 1 rozporządzenia Komisji (WE) nr 1768/95, a w przypadku krajowego odstępstwa rolnego art. 23c ust. 4 pkt 1) ustawy o ochronie prawnej odmian roślin. 
skanie zwrotu kosztów inwestycji związanych z twórczą hodowlą nowych odmian roślin. Sytuacja taka mogłaby prowadzić do zahamowania prac hodowlanych jako nieopłacalnych, a w efekcie do uzależnienia polskich rolników od materiału siewnego odmian roślin hodowanych poza granicami kraju. Odmiany te jednak nie gwarantują należytego dostosowania do polskich warunków klimatycznych i glebowych, a przez to nie gwarantują polskim rolnikom plonów pozwalających na prowadzenie konkurencyjnej produkcji rolnej. Opłaty te co prawda mają mniejsze znaczenie w krajach, gdzie tradycyjnie rolnicy w znacznej części korzystają z licencjonowanego materiału siewnego, jednak mają one kluczowe znaczenie w tych krajach, w których licencjonowany materiał siewny stanowi mniejszość w ogóle materiału wykorzystywanego do siewu. Polska, niestety, należy do tej drugiej kategorii państw Unii Europejskiej.

Jednocześnie bez uprawnień weryfikacyjnych: roszczenia informacyjnego oraz kontrolnego, iluzoryczna stałaby się możliwość realnego dochodzenia przez hodowców roszczeń z tytułu opłaty za korzystanie z instytucji odstępstwa rolnego. Warto bowiem wskazać, że przed wejściem w życie ustawy z dnia 9 czerwca $2006 \mathrm{r}$. o zmianie ustawy o ochronie prawnej odmian roślin i ustawy o nasiennictwie ${ }^{23}$, która to nowelizacja wprowadziła do krajowej instytucji odstępstwa rolnego uprawnienie informacyjne i kontrolne, rolnicy nie uiszczali na rzecz hodowców opłat należnych z tytułu odstępstwa rolnego.

Podkreślić także należy, że równowaga w zakresie praw i obowiązków stron stosunków obligacyjnych wynikających z instytucji odstępstwa rolnego ma zasadnicze znaczenie dla całego modelu ochrony prawnej odmian roślin. Odstępstwo rolne, w ramach którego słuszne interesy hodowcy nie są respektowane, musi prowadzić do erozji wyłącznego prawa do odmian roślin w ogólności. Dlatego też Konwencja UPOV uzależnia możliwość wprowadzenia do porządku prawnego sygnatariusza konwencji tego ograniczenia wyłącznie wtedy, gdy przepisy kreujące tę instytucję zapewniają ochronę interesów hodowców nowych odmian roślin.

\section{Ewolucja krajowej instytucji odstępstwa rolnego}

Pierwszą regulacją statuującą wyłączne prawo do nowych odmian roślin w Polsce była ustawa z dnia 16 lutego $1961 \mathrm{r}$. o hodowli roślin i nasiennictwie ${ }^{24}$, lecz zakładała ona nacjonalizacyjny model tego prawa, po wyhodowaniu nowej odmiany wyłączne prawo do niej podlegało nacjonalizacji ${ }^{25}$. Następnie problematyka ochrony prawnej odmian roślin objęta została postanowieniami ustawy z dnia 10 paź- 
Kilka uwag w przedmiocie projektu nowelizacji ustawy o ochronie prawnej...

dziernika 1987 r. o nasiennictwie ${ }^{26}$. Ustawa ta ukształtowała nowy, prywatnoprawny model ochrony wyłącznego prawa do odmian roślin ${ }^{27}$. Nie wprowadzała ona do polskiego porządku prawnego instytucji odstępstwa rolnego. Tym samym, w trakcie jej obowiązywania rolnicy nie byli uprawnieni do wykorzystywania do siewu materiału odmiany chronionej wyłącznym prawem pochodzącego z ich własnego zbioru.

Instytucja odstępstwa rolnego została wprowadzona do polskiego porządku prawnego ustawą z dnia 24 listopada 1995 r. o nasiennictwie ${ }^{28}$. Art. 26 tej ustawy polski prawodawca zezwalał posiadaczom gruntów rolnych na nieodpłatne wykorzystywanie w ich własnych gospodarstwach materiału pochodzącego ze zbioru odmian roślin chronionych wyłącznym prawem jako materiału siewnego. Posiadacz gruntów rolnych mógł jednak zastosować ten przywilej wyłącznie do obsiania lub obsadzenia uprawy gruntowej o powierzchni do 2 ha.

Jednak zarówno pod rządami ustawy o nasiennictwie z 1987 r., jak i ustawy o nasiennictwie z 1995 r. rozwiązania prawne dotyczące egzekwowania wyłącznego prawa do odmian roślin pozostawały martwe. Podmioty zajmujące się w Polsce twórczą hodowlą nowych odmian roślin (specjalistyczne Państwowe Przedsiębiorstwa Gospodarki Rolnej, a później ich następcy - krajowe spółki hodowli roślin) nie były zainteresowane dochodzeniem swoich praw z tego tytułu wobec faktu, że hodowla twórcza nowych odmian roślin finansowana była ze środków budżetowych. Sytuacja ta uległa zmianie dopiero po akcesji Polski do UE, kiedy to działalność hodowlana nie mogła już być dotowana. Dopiero wówczas konieczne stało się przyjęcie takiej regulacji prawnej, która realnie umożliwiała hodowcom nowych odmian roślin czerpanie zarobkowych korzyści z ich twórczości intelektualnej celem zapewnienia źródeł finansowania dalszych prac badawczych. Odpowiedzią na takie zapotrzebowanie było uchwalenie w dniu 26 czerwca 2003 r. ustawy o ochronie prawnej odmian roślin. Na gruncie tej właśnie ustawy zaczęła kształtować się praktyka stosowania przepisów dotyczących ochrony wyłącznego prawa do odmian roślin, w tym praktyka stosowania instytucji odstępstwa rolnego. Ustawa ta bowiem utrzymała i doprecyzowała przepisy dotyczące instytucji odstępstwa rolnego. Art. 23 ustawy z 2003 r. w jej brzmieniu pierwotnym ustawodawca przesądził o kształcie instytucji odstępstwa rolnego (ust. 1), wprowadził katalog gatunków roślin rolniczych objętych tą instytucją (ust. 2), określił, że dla posiadaczy gruntów rolnych o powierzchni do 5 ha (a w przypadku ziemniaka do 1 lub 2 ha w zależności od tego, czy była to odmiana wczesna) instytucja ta ma charakter przywileju i nie jest związana z koniecznością uiszczania na rzecz hodowcy żadnych opłat (ust. 3 i 4), a także nałożył na pozostałych posiadaczy gruntów rolnych korzystających z odstępstwa rolnego:

26 Dz.U. z 1987 r. Nr 31, poz. 166.

27 Por. Korzycka-Iwanow, Wyłączne prawo do nowej odmiany rośliny uprawnej, op. cit., s. 98 i n.

28 Tekst jedn. Dz.U. z 2001 r. Nr 53, poz. 563. 
- obowiązek uiszczania na rzecz hodowcy opłaty z tytułu korzystania z tej instytucji (ust. 6 i 7), oraz

- obowiązek udzielania hodowcy pisemnych informacji o zakresie korzystania z instytucji odstępstwa rolnego (ust. 8).

Tym samym polski ustawodawca, przyjmując ustawę z dnia 26 czerwca 2003 r. o ochronie prawnej odmian roślin, wprowadził do niej przepisy regulujące opcjonalny wyjątek od prawa hodowcy na zasadach przewidzianych Konwencją UPOV i w kształcie, który miał gwarantować hodowcom poszanowanie ich praw.

Regulacja ta miała niezwykle istotne znaczenie praktyczne. Praktyka korzystania przez rolników (posiadaczy gruntów rolnych) z materiału siewnego odmian roślin chronionych wyłącznym prawem wskazywała bowiem, że zasadnicza większość polskich rolników wykorzystywała do siewu materiał uzyskany uprzednio ze zbioru we własnym gospodarstwie ${ }^{29}$. Jednocześnie podmioty te nie wywiązywały się z obowiązku zapłaty na rzecz hodowców opłaty z tego tytułu. Zjawisko takie prowadziło do erozji wyłącznego prawa do odmiany. Posiadacze gruntów rolnych korzystali z szerokiego dostępu do nowych odmian roślin, kupując niewielkie ilości licencjonowanego materiału siewnego, następnie namnażając ten materiał we własnych gospodarstwach i korzystając z niego bez uiszczania opłat z tego tytułu, a często także wprowadzając go do obrotu bez wiedzy i zgody jego hodowcy. Sytuacja taka doprowadziła do kryzysu polskiej, twórczej hodowli nowych odmian roślin. Polskie spółki hodowlane, odcięte od środków publicznych, zmuszone zostały do podjęcia działań zmierzających do egzekwowania wyłącznego prawa do odmian, w tym prawa do opłaty z tytułu stosowania instytucji odstępstwa rolnego. Mając powyższe na uwadze, polskie spółki hodowlane powołały w 2003 r. swoją organizację ${ }^{30}$, której celem było uporządkowanie polskiego rynku nasiennego poprzez: reprezentowanie interesów hodowców w procesie przestrzegania przepisów prawa dotyczących licencji umownych wyłącznego prawa do odmian roślin uprawnych, zwalczanie nielegalnego rynku materiału siewnego oraz dochodzenie na rzecz hodowców roszczeń z tytułu odstępstwa rolnego.

Praktyka stosowania przepisów ustawy z dnia 26 czerwca 2003 r. o ochronie prawnej odmian roślin w zakresie dotyczącym instytucji odstępstwa rolnego wyka-

Polska Izba Nasienna (organizacja branżowa polskiego przemysłu nasiennego) szacowała, że w roku 2003 (w chwili wejścia w życie ustawy z dnia 26 czerwca 2003 r. o ochronie prawnej odmian roślin zaledwie 7\% spośród wszystkich polskich rolników korzystało z kwalifikowanego materiału siewnego (w tym w przeważającej części był to materiał siewny odmian chronionych wyłącznym prawem). Pozostali rolnicy korzystali bądź z materiału siewnego pochodzącego z własnego rozmnożenia (czyli w przypadku odmian roślin chronionych wyłącznym prawem, z materiału objętego instytucją odstępstwa rolnego), bądź też z materiału siewnego odmian roślin nieobjętych ochroną, a także z materiału siewnego odmian chronionych wyłącznym prawem, lecz pochodzącego ze źródeł nielegalnych (wymiany sąsiedzkiej, sprzedaży bez zgody hodowcy, itp.). 30 Organizacją tą jest Agencja Nasienna Sp. z o.o. Obecnie liczy ona 31 udziałowców. Źródło: www.agencjanasien-
na.pl. 
zała, że posiadacze gruntów rolnych, korzystając z instytucji odstępstwa rolnego, bardzo niechętnie wywiązują się ze swoich zobowiązań wynikających z przepisów prawa. Po pierwsze, podmioty te nie regulowały opłat z tytułu odstępstwa rolnego, o ile nie zostały wezwane do zapłaty z tego tytułu. Po drugie, posiadacze gruntów rolnych ignorowali wnioski hodowców (ich organizacji) o udzielenie pisemnych informacji o zakresie korzystania z instytucji odstępstwa rolnego. Po trzecie, posiadacze gruntów rolnych, jeśli już zdecydowali się na udzielenie takich informacji, to niechętnie przyjmowali próby kontroli ich rzetelności przez hodowców. Ponadto, egzekwowanie przez hodowców ich uprawnień z tytułu odstępstwa rolnego wiązało się z licznymi wątpliwościami interpretacyjnymi wynikającymi z lakonicznej redakcji przepisów art. 23 ustawy o ochronie prawnej odmian roślin.

Sytuacja doprowadziła do podjęcia dyskusji na temat konieczności podjęcia prac $\mathrm{w}$ przedmiocie nowelizacji ustawy o ochronie prawnej odmian roślin w aspekcie dotyczącym instytucji odstępstwa rolnego. Efektem tych prac było uchwalenie ustawy z dnia 9 czerwca 2006 r. o zmianie ustawy o ochronie prawnej odmian roślin i ustawy o nasiennictwie ${ }^{31}$. Nowelizacja ta $z$ jednej strony poszerzyła krąg posiadaczy gruntów rolnych uprawnionych do korzystania z instytucji odstępstwa rolnego bez konieczności ponoszenia $\mathrm{z}$ tego tytułu żadnych opłat ${ }^{32}$. Jednocześnie ustawodawca nowelizując ustawę wprowadził do niej rozbudowaną regulację art. 23a-23c, która uszczegółowiła uprawnienie informacyjne hodowcy oraz wprowadziła możliwość weryfikacji zgodności informacji udzielanych przez posiadaczy gruntów rolnych ze stanem faktycznym. Tym samym polski ustawodawca wprowadził do ustawy o ochronie prawnej odmian roślin ostatnie regulacje gwarantujące równowagę interesów stron instytucji odstępstwa rolnego.

Kolejną nowelizacją, wprowadzoną ustawą z dnia 1 lipca 2011 r. o zmianie ustawy o ochronie prawnej odmian roślin ${ }^{33}$, ustawodawca nie ingerował w zasadnicze mechanizmy odstępstwa rolnego, a jedynie poszerzył katalog gatunków roślin objętych tą instytucją oraz ponownie powiększył kategorię posiadaczy gruntów rolnych zwolnionych z obowiązku uiszczania opłat na rzecz hodowców w związku ze stosowaniem do zasiewu materiału pochodzącego z własnego rozmnożenia ${ }^{34}$. Zmieniona ustawa wprowadziła także możliwość pobierania opłat z tytułu odstępstwa rolnego przez organizację hodowców (art. 23 ust. 7 i 8) oraz doprecyzowała termin

Zgodnie ze znowelizowanym brzmieniem art. 23 ust. 3 ustawy, obowiązek zapłaty nie obciążał posiadaczy gruntów rolnych o powierzchni do 10 ha. W wyniku takiej zmiany liczba podmiotów zobowiązanych do zapłaty z tytułu stosowania instytucji odstępstwa rolnego zmniejszyła się o około 350 tysięcy podmiotów.

$34 \quad Z$ dniem wejścia w życie nowelizacji ustawy, zwolnieni z obowiązku zapłaty z tytułu stosowania odstępstwa rolnego zostali posiadacze gruntów rolnych o powierzchni do 25 ha w przypadku stosowania odstępstwa rolnego w zakresie wszystkich gatunków roślin objętych tą instytucją, z wyjątkiem ziemniaka. W przypadku ziemniaka zobowiązanymi pozostali posiadacze gruntów rolnych o powierzchni 10 ha i większej. 
do udzielenia informacji dotyczących stosowania odstępstwa rolnego (art. 23a ust. 1 oraz art. 23 b ust. 1$)$.

Wskazane wyżej zmiany umożliwiły hodowcom coraz bardziej skuteczne dochodzenie uprawnień wynikających z odstępstwa rolnego. Następstwem tego stanu rzeczy był wzrost wpływów hodowców zarówno z tytułu opłaty od odstępstwa rolnego, jak i z tytułu opłat licencyjnych. Rolnicy bowiem, stojąc przed koniecznością uiszczania opłat $\mathrm{z}$ tytułu korzystania $\mathrm{z}$ materiału siewnego pochodzącego $\mathrm{z}$ własnego rozmnożenia, zaczęli chętniej sięgać po licencjonowany materiał siewny. Efektem był wzrost liczby rolników korzystających rokrocznie z takiego właśnie, licencjonowanego materiału siewnego - z 7\% w roku 2003 do 17\% w roku 2016.

Jednocześnie jednak mechanizm egzekwowania uprawnień hodowców z tytułu odstępstwa rolnego wykazał szereg mankamentów. Po pierwsze, mechanizm ten okazał się niezwykle kosztochłonny. Hodowcy, działający poprzez swoją organizację, zmuszeni są do ponoszenia wysokich kosztów związanych z występowaniem do posiadaczy gruntów rolnych z pisemnymi wnioskami o udzielenie informacji, jak też wysokich kosztów egzekwowania obowiązku udzielania tych informacji. W następstwie czego mechanizm ten nie stał się, ze względów ekonomicznych, mechanizmem powszechnym. Po drugie, jego sformalizowany charakter spotkał się z nieprzychylnym przyjęciem ze strony posiadaczy gruntów rolnych, którzy uznali go za zbyt biurokratyczny i represyjny. Wielu spośród zobowiązanych do udzielenia informacji ignorowało zatem ten obowiązek, nie akceptując go. Efektem takiego stanu rzeczy było szereg postępowań sądowych, w których hodowcy zmuszeni byli dochodzić roszczeń o udzielenie informacji. Postępowania takie spowodowały zaś zaostrzenie się sporu pomiędzy hodowcami i rolnikami. Prowadzone dotychczas negocjacje, w tym przy udziale przedstawicieli Ministerstwa Rolnictwa i Rozwoju Wsi, zmierzające do wypracowania kompromisu w zakresie stosowania instytucji odstępstwa rolnego nie przyniosły do dnia dzisiejszego żadnego pozytywnego rezultatu.

\section{Projekt nowelizacji ustawy o ochronie prawnej odmian roślin}

Następstwem problemów w relacjach pomiędzy hodowcami i posiadaczami gruntów rolnych było podjęcie przez Ministerstwo Rolnictwa i Rozwoju Wsi prac legislacyjnych zmierzających do nowelizacji ustawy o ochronie prawnej odmian roślin $^{35}$. Zgodnie z założeniami projektodawcy, nowelizacja miała zmierzać do stworzenia możliwości przyjmowania przez strony stosunków obligacyjnych odstępstwa 
Kilka uwag w przedmiocie projektu nowelizacji ustawy o ochronie prawnej...

rolnego elastycznych rozwiązań w zakresie pobierania opłat od rozmnożeń własnych $^{36}$.

Realizując taki cel, projektodawca zaproponował wprowadzenie do przepisów art. 23, 23a oraz 23c ustawy postanowień:

- określających uprawnienie hodowcy do ogłoszenia na jego stronie internetowej informacji o zamiarze odstąpienia od pobierania opłat z tytułu odstępstwa rolnego od określonej odmiany w określonym okresie,

- wskazujących, że w czasie obowiązywania ww. ogłoszenia posiadacze gruntów rolnych będą zwolnieni od opłaty z tytułu odstępstwa rolnego w stosunku do ww. odmian roślin,

- dopuszczających możliwość umówienia się stron odstępstwa rolnego (hodowcy i posiadacza gruntów rolnych), że opłata z tytułu odstępstwa rolnego pobierana będzie jednorazowo,

- dopuszczających możliwość odmiennego od ustawowego ukształtowania spoczywającego na posiadaczu gruntów rolnych, obowiązku informacyjnego w drodze umowy z hodowcą (lub jego organizacją),

- dopuszczających możliwość umownego wyłączenia przysługującego hodowcy uprawnienia kontrolnego (uprawnienia do weryfikacji zgodności informacji udzielonych przez posiadacza gruntów rolnych ze stanem faktycznym).

Zaproponowane nowelizacją rozwiązania uznać jednak należy za klasyczny przykład superfluum. Prawo hodowcy do opłaty z tytułu odstępstwa rolnego jest prawem podmiotowym, a co za tym idzie w wyłącznej gestii hodowcy leży, czy prawo to będzie realizował, czy też odstąpi od jego realizacji. Odstępując od realizacji uprawnienia do opłaty z tytułu odstępstwa rolnego, hodowca może posłużyć się wieloma ugruntowanymi i funkcjonującymi instrumentami prawa. Hodowca może zwolnić posiadacza gruntów od długu (art. 508 kodeksu cywilnego), zawrzeć z posiadaczem gruntów rolnych pactum de non petendo, czy też wreszcie nie czynić niczego by roszczenia swojego dochodzić.

Podobnie, zbędną regulację stanowiłyby pozostałe zaproponowane przepisy prawne odnoszące się do treści umowy, jaka mogą zawierać strony stosunków obligacyjnych odstępstwa rolnego. W ramach obecnie obowiązujących przepisów ustawy o ochronie prawnej odmian roślin, strony umowy oznaczonej w art. 23a ust. 4 tej ustawy mogą ukształtować jej treść swobodnie, zgodnie z zasadą swobody umów (art. $353^{1}$ kodeksu cywilnego). W ramach swobody kontraktowej strony mogą także określić, iż opłata z tytułu odstępstwa rolnego może być uiszczana przez posiadacza

Tamże, s. 2. 
gruntów rolnych jednorazowo. Mogą również w odmienny od ustawowego sposób ukształtować zasady przekazywania hodowcom informacji oraz ich kontroli, z wyłączeniem tych uprawnień włącznie.

Ukształtowany w ten sposób projekt nowelizacji ustawy o ochronie prawnej odmian roślin został poddany konsultacjom publicznym. W toku tych konsultacji stanowisko zajęły jedynie trzy podmioty ${ }^{37}$. Wszystkie trzy stanowiska były krytyczne, przy czym stanowisko Polskiej Izby Nasiennej koncentrowało się na wskazanych wyżej problemach związanych ze zbędnością zaproponowanej regulacji, zaś stanowisko Krajowej Rady Izb Rolniczych na niewystarczającym zakresie nowelizacji.

W następstwie ww. konsultacji, w dniu 9 stycznia 2017 r. doszło do zmiany projektu nowelizacji ustawy o ochronie prawnej odmian roślin. Projektodawca, zachowując zapisy dotyczące uprawnienia hodowcy do rezygnacji z pobierania opłat z tytułu odstępstwa rolnego poprzez ogłoszenie zamieszczone na stronie internetowej hodowcy oraz zachowując zapis dotyczący możliwości umownego oznaczenia opłaty od odstępstwa rolnego jako opłaty jednorazowej, dodatkowo zaproponował uchylenie przepisów art. 23a, tj. przepisów statuujących obowiązek udzielenia przez posiadaczy gruntów rolnych informacji o zakresie korzystania z odstępstwa rolnego oraz art. $23 \mathrm{c} w$ zakresie, w jakim przepis ten uprawniał hodowcę do kontroli zgodności takich informacji ze stanem faktycznym. Autor projektu w jego uzasadnieniu wskazał jednoznacznie, iż proponowana zmiana ma na celu zwolnienie wszystkich posiadaczy gruntów rolnych oraz organizacji posiadaczy gruntów rolnych z obowiązu przekazywania hodowcom albo organizacjom hodowców pisemnej informacji dotyczqcej wykorzystania materiatu ze zbioru, który zostat uzyskany $w$ gospodarstwie rolnym i użyty na terenie tego gospodarstwa rolnego ${ }^{38}$. Dodatkowo projektodawca uzasadnit, że zaproponowana zmiana została wprowadzona na wniosek Krajowej Rady Izb Rolniczych ${ }^{39}$.

Projekt w takim brzmieniu został skierowany w dniu 21 lutego 2017 r. do Sejmu.

\section{Wnioski}

Zaproponowany projekt nowelizacji ustawy o ochronie prawnej odmian roślin ocenić należy krytycznie. Przede wszystkim wyłącza on wszystkie mechanizmy służące równoważeniu interesów stron odstępstwa rolnego, tj. obowiązek informacyjny oraz uprawnienie kontrolne hodowców. Wejście w życie zaprojektowanej w ten sposób zmiany sprawi, że ograniczenie prawa hodowcy przekroczy rozsqdne gra- 
Kilka uwag w przedmiocie projektu nowelizacji ustawy o ochronie prawnej...

nice i nie będzie uwzględniać konieczności ochrony interesów hodowców. Tym samym będzie ono sprzeczne z postanowieniami art. 5 ust. 2 Konwencji UPOV.

Ponadto, zaproponowana w ten sposób zmiana nie czyni zadość podstawowemu celowi nowelizacji wskazanemu w treści jej uzasadnienia, tj. nie stworzy ona warunków do elastycznego, umownego ukształtowania stosunków umownych pomiędzy posiadaczami gruntów rolnych a hodowcami. Pozostawienie w polskim porządku prawnym krajowej instytucji odstępstwa rolnego pozbawionej uprawnienia informacyjnego i kontrolnego hodowcy sprawi, że korzystanie $\mathrm{z}$ tej instytucji w praktyce stanie się nieodpłatne. Hodowca nie będzie bowiem posiadał żadnego instrumentu prawnego pozwalającego zweryfikować istnienie obowiązku zapłaty opłaty z tytułu korzystania przez rolnika z materiału pochodzącego z własnego rozmnożenia. Tym samym należy oczekiwać powrotu do stanu sprzed roku 2003, tj. sytuacji, w której ochrona wyłącznego prawa do odmian roślin w Polsce, w stosunku do odmian chronionych na szczeblu krajowym, stanie się w istocie iluzoryczna. Najprawdopodobniej skutkiem będzie ograniczenie zapotrzebowania na licencjonowany materiał siewny, rozpowszechnienie się szarej strefy obrotu materiałem siewnym i znaczący spadek wpływów polskich spółek hodowlanych. Zarazem, posiadacze gruntów rolnych nie będą w żaden sposób motywowani do poszukiwania kompromisu poprzez umowne uregulowanie stosunków prawnych wynikających z instytucji odstępstwa rolnego.

Co więcej, projektodawca zdaje się nie dostrzegać, że przyjęcie zaproponowanych przez niego rozwiązań odbije się negatywie na sytuacji prawnej wyłącznie tych hodowców, którzy chronią swoje odmiany na szczeblu krajowym. W przypadku odmian roślin chronionych na szczeblu wspólnotowym sytuacja prawna nie ulegnie natomiast zmianie. Oznacza to, że hodowcy (i ich organizacje) będą nadal uprawnieni do domagania się informacji oraz do kontroli ich zgodności ze stanem faktycznym w przypadku odmian chronionych wyłącznym prawem na podstawie przepisów rozporządzenia Rady (WE) nr 2100/94. Zważywszy, że około 65\% wykorzystywanego w Polsce materiału siewnego to materiał odmian roślin chronionych na szczeblu wspólnotowym, znowelizowana ustawa znajdzie jedynie bardzo ograniczone zastosowanie. Ponadto, preferowany zostanie wspólnotowy model ochrony wyłącznego prawa do odmian roślin, co postawi w pozycji uprzywilejowanej hodowców zagranicznych kosztem polskich spółek hodowli twórczej.

Mając powyższe na uwadze należy mieć nadzieję, że kształt zaproponowanej nowelizacji ustawy o ochronie prawnej odmian roślin nie zyska aprobaty w toku prac Sejmowej Komisji Rolnictwa i ulegnie on ostatecznie zmianie uwzględniającej słuszne interesy hodowców nowych odmian roślin. 


\section{SEVERAL CONCERNS REGARDING THE PROPOSED AMENDMENT OF THE PLANT VARIETY PROTECTION ACT}

Keywords: legal protection of plant varieties, industrial property rights. Intellectual property, agricultural exemption.

The institution of agricultural exemption is the most significant economic importance from all limitations to the exclusive right to the plant varieties. The agricultural exemption shall mean the derogation from the assumed protection model of plant variety rights, the objective of which is to defend the interests of farmers. Protecting the interests of farmers within the institution concerned is provided through their entitlement to benefit from the material harvested from plant varieties protected by the exclusive right as the seed without the breeder's consent.

So far-restricting protection of the exclusive right to the variety may lead to disintegration of the referred right, unless the legislator ensures the breeders legal instruments to offset their legitimate interests. Both at the Community and the national level such instruments shall be the entitlement to collect a fee for the agricultural exemption, the entitlement of the breeder to demand the information on a scope of the use of the institution of agricultural exemption, as well as the entitlement to check the compliance of the obtained information with the actual data.

The latest draft amendment to the plant variety protection act fails to satisfy the principle to balance interests of the parties for obligatory relations of the agricultural exemption. In Poland its potential adoption and coming into force may be the essential factor which shall make the protection of the exclusive right regarding plant varieties at national level illusory.

Bibliografia:

Gała P., Korzycka-Iwanow M., Ochrona prawna odmian roślin, (w:) System Prawa Prywatnego, Tom 14A, Prawo własności przemysłowej, R. Skubisz (red.), Warszawa 2012.

Korzycka-Iwanow M., Wyłączne prawo do nowej odmiany rośliny uprawnej, Wydawnictwa Uniwersytetu Warszawskiego, Warszawa 1990. 